\title{
POR ENTRE NARRATIVAS E DOCUMENTOS ESCRITOS: UMA HISTÓRIA DA ESCOLA PRIMÁRIA NO SUL DE SERGIPE (1930-1960)
}

\author{
BETWEEN NARRATIVES AND WRITTEN DOCUMENTS: \\ A HISTORY OF THE PRIMARY SCHOOL IN THE SOUTH OF SERGIPE \\ (1930-1960)
}

\author{
Raylane Andreza Dias Navarro Barreto ${ }^{1}$
}

Laísa Dias Santos ${ }^{2}$

\begin{abstract}
RESUMO: Sob inspiração da História Cultural, este artigo tem como objetivo analisar os diferentes tipos de escolas primárias existentes nos territórios centrosul e sul do estado de Sergipe, entre os anos 1930 e 1960. A análise, que privilegiou o cruzamento de documentos escritos e memórias de professores, revelou que à revelia das reformas educativas e do ideal de escola que elas pressupunham, sua configuração esteve subordinada aos financiamentos e planos nacionais, e, principalmente, às condições políticas, materiais, culturais e intelectuais dos atores que estiveram diretamente envolvidos em seus específicos processos. Nesse sentido, a união da narrativa e de discursos oficiais possibilitou a compreensão de uma pluralidade de sentidos que, além de agregarem características particulares à História da escola primária sergipana, também abrem possibilidades para novas versões, escrita e do ensino da História.
\end{abstract}

Palavras-chave: Escola primária. Sergipe. Memória. Documento escrito.

\begin{abstract}
Under Cultural History inspiration, this article aimed to analyze the different types of primary schools in the South Central and southern state of Sergipe between 1930 and 1960. The analysis, which benefit the intersection of written documents and teachers' memories, revealed that the configuration of educational reforms and its school model was subordinate to funds and national plans, mostly to political conditions, materials, cultural and intellectual of the agents who were involved in their specific processes. So, the narrative and official speeches connection made possible the understanding of a plurality of meanings which added particular characteristics to Sergipe's primary school history. In addition, it opens possibilities for new versions, writing and teachingof history.
\end{abstract}

Keywords: Primary school. Sergipe. Memory official. Document.

\footnotetext{
${ }^{1}$ Professora do Centro de Educação da Universidade Federal de Pernambuco-UFPE. Líder do Grupo de Estudos e Pesquisas Interdisciplinar em Formação Humana, Representações e Identidades- GEPIFHRI. Doutora em Educação pela Universidade Federal do Rio Grande do Norte-UFRN. E-mail: raylanenavarro@bol.com.br.

2 Doutoranda em Educação pela Universidade Federal de Sergipe-UFS. Mestre em educação pela Universidade Tiradentes-UNIT. Membro do Grupo de Estudos e Pesquisas em História da Educação memórias, sujeitos, saberes e práticas educativas- GEPHED. E-mail: laisadias10@gmail.com.
} 


\section{Introdução}

No período de predomínio dos ideais da Escola Nova (1930-1960), a propaganda republicana sobre instrução pública circulou em torno da eficácia e implementação da escola seriada, o que envolvia, para além da arquitetura, a materialidade, os métodos de ensino e quadro de funcionários. Por outro lado, trabalhos oriundos do projeto Memória Oral da Educação Sergipana ${ }^{3}$, que tomaram como objeto/fonte de pesquisa memórias de professores, apontam que a pari passo deste alardeado processo de expansão dos grupos escolares, outros tipos de escolas, consideradas aquém do ideal em termos de estrutura física e material, também tiveram papel essencial na instrução pública do estado de Sergipe. Desse modo, ao considerar as contradições, afastamentos e conflitos entre os discursos, algumas questões foram levantadas, tais como: que tipos de escolas primárias existiram no cronótopo analisado? Como se delineou este processo de expansão? A implantação das escolas primárias condizia aos discursos oficiais apresentados? Quais elementos contribuíram para a manutenção de escolas "não ideais"?

Ao tomarmos como objeto de estudo as escolas primárias, em especial os grupos escolares existentes nos territórios do centro-sul e sul do estado de Sergipe, entre os anos de 1930 e 1960, este trabalho buscou analisar os diferentes tipos de escolas existentes no espaço e tempo estudados. Para empreender esta investigação, o trabalho seguiu os pressupostos da História Cultural, corrente teórica que amplia o campo de análise, objetos de estudos e fontes de pesquisa para além do que envolve a História factual, permitindo, assim, que o presente possa adquirir sentido, o outro tornar-se inteligível e o espaço ser decifrado por meio de esquemas intelectuais produzidos pelas disposições estáveis e partilhadas pelos

\footnotetext{
${ }^{3}$ Tal projeto, subsidiado pelo Edital MCTI/CNPq/MEC/CAPES No 18/2012 e pelos Programas de Iniciação Científica CNPQ, PROVIC/UNIT e PROBIC/UNIT, foi coordenado por Raylane Andreza Dias Navarro Barreto e teve como objetivo compreender os modos de educar desenvolvidos por professores sergipanos. Atualmente, conta com um acervo audiovisual de 145 entrevistas com professores de faixa etária entre 55 e 103 anos, que estudaram e ensinaram no estado.
}

História \& Ensino, Londrina, v. 25, n. 1, p. 453-483, jan./jun. 2019 
interesses do grupo que as forja e da posição de quem os utiliza (CHARTIER, 1990). Desta maneira, os estudos empreendidos a partir deste pressuposto devem buscar "[...] compreender como, em cada época, tecem-se relações complexas entre formas impostas, mais ou menos restritivas, e identidades salvaguardadas, mais ou menos alteradas" (CHATIER, 2010, p. 46). É aí, segundo o autor, que se apresenta o principal desafio da História Cultural e dos trabalhos que nela se ancoram: pensar a articulação entre os discursos e as práticas.

Como forma de pensar maneiras de articular discursos oficiais às narrativas de história de vida e assim interpretar as brechas que neles se inserem, recorremos à abordagem da História vista de baixo. Essa abordagem se apresenta como uma forma de compreender os fatos por meio da união da História do cotidiano das pessoas comuns com tipos mais tradicionais da História (SHARPE, 2011), como, por exemplo, aquela baseada apenas em livros, leis, decretos e outros documentos escritos. Por meio da abordagem da História vista de baixo, somada à possibilidade de narrativas de sujeitos simples apropriadas como documento, foram selecionadas 29 narrativas de História de vida de professores ${ }^{4}$ aposentados, como uma das fontes de pesquisa deste trabalho. Eles têm idade entre 55 e 103 anos, estudaram e, posteriormente, se tornaram professores com formação primária, ginasial ou superior, nas 17 cidades que compõem os territórios centro e sul de Sergipe. As entrevistas audiovisuais, que tiveram duração entre 30 minutos e oito horas ${ }^{5}$, foram gravadas entre os anos de 2011 e 2015.

Para lidar com narrativas e com o intuito de sedimentar este tipo de fonte servindo à História, a metodologia da História Oral nos foi válida.

${ }^{4}$ Foram entrevistados os seguintes professores: Acinete Almeida Bispo; Amariles Gomes Moura; Ana Rodrigues de Menezes; Antônio Barros Vasconcelos; Cordélia do Nascimento Costa; Eleonora Leite Pereira; Elienalda Souza Reis; Janice Santos Silva; José Walter Leonidio da Silva; Josefa de Andrade Fontes; Josefa Maria da Conceição; Josefa Santana da Silva; Josefina Batista Hora; Laudicéia Rodrigues Cerqueira; Lindinalva Oliveira de Santana; Luzia Honória dos Santos; Maria Auxiliadora de Oliveira; Maria Costa Góis; Maria do Carmo Fontes Silva; Maria dos Santos Santana; Maria Isabel dos Santos; Maria Lita Silveira; Maura Fontes Hora; Olda do Prado Dantas; Raimunda Maria de Jesus; Raimunda Alves dos Santos; Risoneuma Soares Feitosa; Rivanda Alves de Oliveira Cabral.

${ }^{5}$ A duração das entrevistas variou de professor para professor, pois foram respeitados os limites físicos, a disponibilidade de tempo e a fluência da narrativa de cada um. 
Como forma de ampliar o conhecimento sobre acontecimentos e conjunturas do passado, a metodologia da História Oral, uma vez respaldada na História Cultural, possibilita que a História e seus mais variados campos, dentre eles a Educação, possam ser compreendidos a partir do processo de rememoração do passado. Deste modo, ela vem se consolidando como uma forma de fazer historiográfico que tem por base as maneiras pelas quais cada indivíduo lembra/esquece pessoas, lugares e episódios. Segundo Paul Thompson (1992),

\begin{abstract}
Enquanto os historiadores estudam os atores da história a distância, a caracterização que se fazem de suas vidas, opiniões e ações sempre estará sujeita a ser descrições defeituosas, projeções da experiência e da imaginação do próprio historiador: uma forma erudita de ficção. A evidência oral, transformando os 'objetos' de estudo em 'sujeitos', contribui para uma história que não só é mais rica, mais viva e mais comovente, mas também mais verdadeira (THOMPSON, 1992, p. 137).
\end{abstract}

No processo de análise das narrativas, além das potencialidades da memória, como por exemplo, os fatos particulares de cada História de vida, nos deparamos com esquecimentos, incertezas, invenções e reinterpretações, que por natureza também compõem o processo rememorativo. Mas, como lidar com tais empecilhos? Em muitos momentos da análise, principalmente no estabelecimento de datas, nomes de pessoas e lugares, eles precisaram ser supridos. Isso porque imprecisões como estas poderiam acarretar anacronismos e interpretações incongruentes. Nesse sentido, e em prol de uma História vista de baixo, elegemos ainda como fonte de pesquisa: Mensagens de Governadores do estado; Relatórios de diretores da instrução pública de Sergipe; Leis e decretos voltados para a Educação e Revistas do Instituto Nacional de Estudos Pedagógicos (INEP).

Os documentos oficiais e textuais não assumiram e nem poderiam assumir a função de evidenciar o real e de corrigir erros, lapsos, equívocos ou imprecisões da memória, afinal, como considerou Le Goff (1990, p. 53) "[...] não existe um documento-verdade. Todo documento é mentira". Isso porque o documento "[...] não é qualquer coisa que fica por conta do passado, é um produto da sociedade que o fabricou segundo as relações de 
forças que aí detinham o poder" (LE GOFF, 1990, p. 54). Entendido desta maneira, tornou-se possível desfazer a ideia de que os documentos/oficiais são guardiões de uma única verdade para considerar que, somados às representações, é possível se escrever uma História mais contraditória, emocionante, problemática, inquietadora, fragmentada, enfim, mais ampla e próxima do real. Com este propósito, buscamos empreender as discussões sobre o delineamento da escola primária em Sergipe.

\section{Discursos oficiais e narrativas de professores: em destaque os tipos de escolas primárias (1930-1947)}

O Grupo Escolar Modelo, inaugurado em 1911 na capital Aracaju, foi a primeira escola desta natureza a funcionar no estado de Sergipe (SANTOS, 2013). A partir do Decreto estadual no 536, expedido em 12 de agosto de 1911 pelo então presidente ${ }^{6}$ do estado José Rodrigues da Costa Dórea, ficou organizado o ensino em grupos escolares. Como forma de cumprir o que já havia disposto tal decreto, foi inaugurado no ano de 1914, na capital Aracaju, o Grupo Escolar Central, seguido da construção do Grupo Escolar General Valadão e do Grupo Escolar Barão de Maruim. Ainda no governo de Manoel Prisciliano de Oliveira Valadão (1914-1918) foi construído, em 1918, o Grupo Escolar Coelho e Campos, o primeiro a ser implantado no interior do território sergipano. Quatros anos depois, no governo de Graccho Cardoso (1922-1926), foram inaugurados mais 11 escolas graduadas, a saber:

Grupo Escolar Gumersindo Bessa (1923); Grupo Escolar Vigário Barroso (1923); Grupo Escolar General Valladão (1923); Grupo Escolar Silvio Romero (1924); Grupo Escolar Dr. Manuel Luiz (1924); Grupo Escolar José Ferraz (1925); Grupo Escolar Fausto Cardoso (1925); Grupo Escolar Coronel João Fernandes (1925); Grupo Escolar Olímpio Campos (1925); Grupo Escolar Coelho e Campos (1926); e Grupo Escolar Severiano Cardoso; Fausto Cardoso (1926). (SANTOS, 2013, p. 91-92).

\footnotetext{
${ }^{6} \mathrm{O}$ termo Presidente do estado foi substituído por Governador em Sergipe no ano de 1937.
} 
De acordo com Santos (2013), ao final do ano de 1926 o cenário educacional sergipano contava com "14 Grupos escolares e 16 prédios escolares, com características monumentais". Este processo de construção e expansão que envolvia, além da arquitetura, a materialidade, os métodos de ensino e quadro de funcionários, estava envolto a um discurso político que percebia as reformas como necessárias, mas, também, "dispendiosas" e com grande "peso no orçamento" estadual. As justificativas para os avanços e retrocessos na instrução pública sergipana, para além de discursos governamentais, também estiveram presentes no relatório apresentado ao governo interventorial, em 1931, pelo diretor da instrução pública Helvécio de Andrade. Em mensagem governamental, ele apresentou a seguinte problemática: "Que dizer de Sergipe, pequeno, pobre, esquecido, em suas maiores necessidades?... Vai fazendo o possível, avançando aqui, tropeçando acolá, erguendo-se depois mais vigoroso, no seu grande desejo de crescer" (SERGIPE, 1931, p. 2).

As palavras de Helvécio de Andrade apontam para um enaltecimento do estado em relação à educação, contudo também revelam, de forma tímida, as fragilidades causadas por impasses econômicos, demográficos, históricos e políticos. Dentre tais impasses, o que mais esteve presente nas mensagens de governadores analisadas, mesmo que nas entrelinhas e escamoteadas por palavras de esperança, compromisso e trabalho, foram as dificuldades financeiras tanto para seguir na construção dos grupos escolares majestosos como também para os "vencimentos do professorado". Nesse sentido, a era dos imponentes grupos escolares, que tinham entre seus propósitos "educar pelo visual e encantar pela grandiosidade", teve fim no ano de 1926. Sergipe, assim como outros estados brasileiros, apostou, senão nos grupos escolares mais modestos (no tocante à arquitetura e estrutura física), em uma simbiose entre majestade, simplicidade e precariedade. Assim, suntuosos, modestos ou impróprios, o estado de Sergipe seguiu na construção e expansão de grupos escolares, direcionando-a por todo o estado no período estudado da seguinte maneira: 
Tabela 1 - Expansão dos grupos escolares pelo estado entre os anos de 1930-1960

\begin{tabular}{|l|l|l|l|l|l|l|}
\hline Regiões & $\begin{array}{l}\text { No de } \\
\text { cidade } \\
\text { s }\end{array}$ & $\begin{array}{l}\text { Déc. de } \\
\mathbf{1 9 3 0}\end{array}$ & $\begin{array}{l}\text { Déc. de } \\
\mathbf{1 9 4 0}\end{array}$ & $\begin{array}{l}\text { Déc. de } \\
\mathbf{1 9 5 0}\end{array}$ & $\begin{array}{l}\text { Ano } \\
\text { de } \\
\mathbf{1 9 6 0}\end{array}$ & TOTAL \\
\hline Alto Sertão & 7 & & & 2 & & 2 \\
\hline Agreste Central & 14 & 1 & & 4 & & 5 \\
\hline $\begin{array}{l}\text { Baixo São } \\
\text { Francisco }\end{array}$ & 14 & & & 4 & & 4 \\
\hline Médio Sertão & 6 & & & 2 & & 2 \\
\hline Leste Sertão & 9 & & 2 & 1 & 2 & 5 \\
\hline Sul Sergipano & $\mathbf{1 1}$ & & & $\mathbf{4}$ & & $\mathbf{4}$ \\
\hline $\begin{array}{l}\text { Centro-sul } \\
\text { sergipano }\end{array}$ & $\mathbf{5}$ & & $\mathbf{1}$ & $\mathbf{1}$ & & $\mathbf{2}$ \\
\hline Grande Aracaju & 9 & 2 & 1 & 2 & 1 & 6 \\
\hline Total & & 3 & 4 & 20 & 3 & $\mathbf{3 0}$ \\
\hline
\end{tabular}

Fonte: Tabela elaborada pelas autoras a partir de mensagens de governadores emitidas entre os anos de 1930 a 1960.

Como é possível perceber, a partir da Tabela 1, foi na década de 1950 que as oito regiões do estado de Sergipe foram contempladas, em quantidades diferentes, com a criação de grupos escolares. Esta ampliação, que esteve atrelada às iniciativas políticas nacionais direcionadas ao ensino primário rural, em especial as alavancadas pelo Instituto Nacional de Estudos Pedagógicos (Inep), contribuiu para que, nesta década, fossem construídos 20 dos 30 grupos escolares edificados entre os anos de 1930 e 1960 por todo o estado. Deste montante, seis grupos fizeram parte do espaço delimitado, dentre eles cinco com características rurais como o Lourival Fontes, Olympio Campos, Manuel Bonfim, Comendador Calazans e Alencar Cardoso, localizados, respectivamente, nas cidades de Riachão do Dantas, Itabaianinha, Santa Luzia do Itanhy e Salgado; e apenas o Grupo Escolar Tobias Barreto (1943) com atributos de uma escola urbana.

Por motivos econômicos, políticos ou como estratégias de distribuição para melhor atender às demandas do estado, há que se considerar que a

\footnotetext{
${ }^{7}$ Ele foi o único a ser construído nas regiões delimitadas no período que compreende o fim das construções arquitetônicas suntuosas (1926) e o projeto de expansão das escolas rurais (1947).
} 
presença dos grupos escolares em cidades do interior atribuía ao local um destaque diante dos outros municípios, pois a presença da escola graduada simbolizava e evidenciava que ali estavam de fato sendo disseminados os ideais republicanos. Contudo, há evidências de que eles não conseguiam atender toda a demanda. A narrativa da professora Josefa Santana da Silva, de 84 anos de idade, revelou a necessidade de outros tipos de escolas para que a população em idade escolar, da cidade de Lagarto, na década de 1930, fosse atendida. De acordo com a entrevistada, apesar do "Grupo ser de graça e uma escola tradicional [...] para se ter uma vaga naquele época era um servição". Por isso, na década de 1930 existiram, em consonância com o Grupo Escolar Sylvio Romero, outros tipos de escolas que, muitas vezes, eram bem mais acessíveis e próximas da população. Ela explica que esse "servição" era por conta da dificuldade que os alunos enfrentavam para encontrar vaga no grupo escolar, não restando outra alternativa a não ser estudar em escolas particulares, como as de "dona Filomena, dona Cecília e Seu Cazuza", que eram irmãos, ou das "professoras Josefa e Elvira", estas últimas onde a professora estudou o primeiro e segundo anos do ensino primário.

A partir dos discursos, acima mencionados, sobre modernização educacional e avanços na expansão e aceitação dos grupos escolares, foi possível encontrar evidências que nomeiam e quantificam o que a entrevistada Josefa Santana da Silva deu a ver por meio da sua narrativa. Trata-se de outros tipos de escolas e a quantidade de alunos que as frequentavam. As mensagens de governadores emitidas nos anos de 1930, 1935, 1936 e 1937, bem como do relatório da instrução pública apresentado em 1943, há ausências e diferenciações que chamam a atenção. No início da década de 1930, evidenciou-se de forma nítida a frequência dos alunos nos variados tipos de escolas existentes no estado, revelando, assim, que ficava a cargo das escolas isoladas o maior número de alunos. Entretanto, a partir do ano de 1935, tais estatísticas não mais foram publicadas, ao menos de forma tão explícita. Também foi possível perceber que no governo interventorial de Augusto Maynard Gomes (1930- 
1934 e 1942-1945) as escolas eram identificadas de forma mais específica (escolas isoladas, particulares, grupos escolares da cidade e do interior, escolas reunidas), no governo de Eronildes Ferreira de Carvalho (19351941) elas eram destacadas de forma mais ampla (escolas municipais e estaduais).

Talvez, se as narrativas de alunos/professores não suscitassem a permanência de escolas tidas como não "ideais", esta diferença entre nomenclaturas não representasse nenhuma "intenção" nos discursos políticos. Uma vez que a memória do entrevistado pode trazer à tona a presença do passado, esse que pode ser analisado conforme a apropriação ou os "[...] significados atribuídos por quem o vivenciou (ALBERTI, 2004, p. 35) a presença/ausência de determinados tipos de escolas abre brechas para se pensar se o uso de terminologias mais gerais não dificultariam a identificação dos tipos de escolas que, uma vez não condizentes às propostas educacionais vigentes, ainda compunham o cenário educativo sergipano.

Quiçá pelo número de vagas, ou pela distância em que os grupos escolares poderiam se encontrar da casa dos alunos, dos 29 entrevistados apenas as professoras Amariles Gomes de Moura (Boquim), Ana Rodrigues de Menezes (Lagarto), Josefa Santana da Silva (Lagarto), Laudicéia Rodrigues Cerqueira (Arauá), Olda do Prado Dantas (Simão Dias), Risoneuma Soares Feitosa (Umbaúba), Josefa de Andrade Fontes (Itabaianinha) e Maria Auxiliadora Oliveira (Tobias Barreto) estudaram e/ou ensinaram em grupos escolares das regiões do centro-sul e sul. Por meio das suas lembranças foram rememorados apenas seis grupos escolares: o Grupo Escolar Sylvio Romero, Grupo Escolar Manoel Bonfim, Grupo Escolar Severiano Cardoso, Grupo Escolar Fausto Cardoso e Grupo Escolar Tobias Barreto.

Apesar das escolas graduadas não contemplarem a maior parte da população em idade escolar no tempo analisado, os discursos políticos deixavam as escolas precárias à sombra delas. A ideia propagada era a de que o governo estava tentando seguir na construção de grupos escolares, 
aumentando significativamente o número de interessados e, consequentemente, uma demanda por matrícula. Isso porque eles perfaziam o tipo de escola ideal para a propagação das primeiras letras, pois para além de menos dispendiosos, se comparados às escolas isoladas, reuniam métodos eficazes, professores qualificados, espaço apropriado e material didático condizente às necessidades de aprendizagem do aluno. Este pode ser um dos motivos que deu aos grupos escolares presentes no estado de Sergipe destaque em todas as mensagens emitidas, não só entre os anos de 1930 e 1947, mas, também, nos anos que se seguiram até 1960. Tais grupos foram relacionados no quadro a seguir:

Quadro 1 - Grupos escolares construídos e/ou em funcionamento entre os anos de 1930 e 1960 no estado de Sergipe

\begin{tabular}{|c|c|c|}
\hline MUNICÍPIOS & DENOMINAÇÃO & $\begin{array}{l}\text { ANO DE INAUGURAÇÃO } \\
\text { OU CONSTRUCCÃO }\end{array}$ \\
\hline 1. Aracaju & $\begin{array}{l}\text { Grupo Escolar General } \\
\text { Siqueira }\end{array}$ & $\begin{array}{l}\text { Em funcionamento } \\
\text { (mensagem de } 1930 \text { ) }\end{array}$ \\
\hline 2. Aracaju & $\begin{array}{l}\text { Grupo Escolar Barão de } \\
\text { Maruim }\end{array}$ & $\begin{array}{l}\text { Em funcionamento } \\
\text { (mensagem de } 1930 \text { ) }\end{array}$ \\
\hline 3. Aracaju & $\begin{array}{l}\text { Grupo Escolar Dr. Manuel } \\
\text { Luiz }\end{array}$ & $\begin{array}{l}\text { Em funcionamento } \\
\text { (mensagem de } 1930 \text { ) }\end{array}$ \\
\hline 4. Aracaju & $\begin{array}{l}\text { Grupo Escolar General } \\
\text { Valadão }\end{array}$ & $\begin{array}{l}\text { Em funcionamento } \\
\text { (mensagem de 1930) }\end{array}$ \\
\hline 5. Aracaju & $\begin{array}{lll}\text { Grupo Escolar José } \\
\text { Augusto Ferraz }\end{array}$ & $\begin{array}{l}\text { Em funcionamento } \\
\text { (mensagem de 1930) }\end{array}$ \\
\hline 6. Aracaju & $\begin{array}{l}\text { Grupo Escolar Rural Ivo } \\
\text { do Prado }\end{array}$ & $\begin{array}{l}\text { Em funcionamento } \\
\text { (mensagem de 1953) }\end{array}$ \\
\hline 7. Arauá ${ }^{8}$ & $\begin{array}{l}\text { Grupo Escolar } \text { Rural } \\
\text { Manoel Bonfim }\end{array}$ & $\begin{array}{l}\text { Em construção } \\
\text { (mensagem 1951) } \\
\text { Em funcionamento } \\
\text { (mensagem de 1953) }\end{array}$ \\
\hline $\begin{array}{l}\text { 8. Barra } \\
\text { Coqueiros }\end{array}$ & $\begin{array}{l}\text { Grupo Escolar (não } \\
\text { nomeado na mensagem } \\
\text { analisada) }\end{array}$ & $\begin{array}{l}\text { Entregue (mensagem de } \\
\text { 1960) }\end{array}$ \\
\hline 9. Boquim & $\begin{array}{ll}\text { Grupo } & \text { Escolar } \\
\text { Severiano Cardoso }\end{array}$ & $\begin{array}{l}\text { Em funcionamento } \\
\text { (mensagem de 1930) }\end{array}$ \\
\hline 10. Campo do Brito & $\begin{array}{lll}\text { Grupo Escolar } & \text { Rural } \\
\text { Guilherme Campos } & \end{array}$ & $\begin{array}{l}\text { Construído (mensagem de } \\
1951 \text { ) } \\
\text { Em funcionamento } \\
\text { (mensagem de 1953) }\end{array}$ \\
\hline 11. Capela & $\begin{array}{l}\text { Grupo Escolar Coelho e } \\
\text { Campos }\end{array}$ & $\begin{array}{l}\text { Em funcionamento } \\
\text { (mensagem de 1930) }\end{array}$ \\
\hline
\end{tabular}

${ }^{8} \mathrm{O}$ negrito serve para destacar as cidades delimitas como lócus da pesquisa. 


\begin{tabular}{|c|c|c|}
\hline 12. Carira & $\begin{array}{lll}\text { Grupo } & \text { Escolar } & \text { Artur } \\
\text { Fortes } & & \end{array}$ & $\begin{array}{l}\text { Construído (mensagem de } \\
1958 \text { ) }\end{array}$ \\
\hline 13. Cumbe & $\begin{array}{l}\text { Grupo Escolar Alcebiades } \\
\text { Paes }\end{array}$ & $\begin{array}{l}\text { Construído (mensagem de } \\
1958 \text { ) }\end{array}$ \\
\hline $\begin{array}{l}\text { 14. Darcilena (Cedro } \\
\text { de São João) }\end{array}$ & $\begin{array}{lcl}\text { Grupo } & \text { Escolar } & \text { Rural } \\
\text { Manoel Dantas } & \end{array}$ & $\begin{array}{l}\text { Em construção (mensagem } \\
\text { de 1951) } \\
\text { Em funcionamento } \\
\text { (mensagem de 1953) }\end{array}$ \\
\hline 15. Divina Pastora & $\begin{array}{l}\text { Grupo Escolar (não } \\
\text { nomeado na mensagem } \\
\text { analisada) }\end{array}$ & $\begin{array}{l}\text { Entregue (mensagem de } \\
\text { 1960) }\end{array}$ \\
\hline 16.Estância & $\begin{array}{l}\text { Grupo } \quad \text { Escolar } \\
\text { Gumersindo Bessa }\end{array}$ & $\begin{array}{l}\text { Em funcionamento } \\
\text { (mensagem de 1930) }\end{array}$ \\
\hline 17. Frei Paulo & $\begin{array}{lll}\text { Grupo Escolar Rural } \\
\text { Martinho Garcez }\end{array}$ & $\begin{array}{l}\text { Construído (mensagem de } \\
1950 \text { ) } \\
\text { Em funcionamento } \\
\text { (mensagem de 1953) }\end{array}$ \\
\hline 18. Gararu & $\begin{array}{l}\text { Grupo Escolar Monsenhor } \\
\text { Rangel }\end{array}$ & $\begin{array}{l}\text { Em funcionamento } \\
\text { (mensagem de 1954) }\end{array}$ \\
\hline 19. Itabaiana & $\begin{array}{l}\text { Grupo } \\
\text { Guilhermino Bezerra }\end{array}$ & $\begin{array}{l}\text { Aparece na mensagem de } \\
1936\end{array}$ \\
\hline 20.Itabaianinha & $\begin{array}{l}\text { Grupo Escolar Rural } \\
\text { Olímpio Campos }\end{array}$ & $\begin{array}{l}\text { Construído (mensagem } \\
\text { de 1950) } \\
\text { Em funcionamento } \\
\text { (mensagem de 1953) }\end{array}$ \\
\hline $\begin{array}{l}\text { 21. Itaporanga } \\
\text { D'Ajuda }\end{array}$ & $\begin{array}{lll}\text { Grupo } & \text { Escolar } & \text { Rural } \\
\text { Felisbelo Freire } & \end{array}$ & $\begin{array}{l}\text { Construído (mensagem de } \\
1951 \text { ) } \\
\text { Em funcionamento } \\
\text { (mensagem de 1953) }\end{array}$ \\
\hline 22. Japaratuba & $\begin{array}{l}\text { Grupo Escolar Senador } \\
\text { Gonçalo Rollemberg }\end{array}$ & $\begin{array}{l}\text { Em funcionamento } \\
\text { (Departamento de Inspeção } \\
\text { Escolar- década de 1940) }\end{array}$ \\
\hline 23. Japoatã & $\begin{array}{l}\text { Grupo Escolar } \\
\text { Josino Menezes }\end{array}$ & $\begin{array}{l}\text { Construído (mensagem de } \\
1950 \text { ) } \\
\text { Em funcionamento } \\
\text { (mensagem de 1953) }\end{array}$ \\
\hline 24. Lagarto & $\begin{array}{l}\text { Grupo Escolar Sylvio } \\
\text { Romero }\end{array}$ & $\begin{array}{l}\text { Em funcionamento } \\
\text { (mensagem de 1930) }\end{array}$ \\
\hline 25. Laranjeiras & $\begin{array}{lll}\text { Grupo } & \text { Escolar } & \text { João } \\
\text { Ribeiro } & & \\
\end{array}$ & $\begin{array}{l}\text { Aparece na mensagem de } \\
1936\end{array}$ \\
\hline 26. Maruim & $\begin{array}{lll}\text { Grupo } & \text { Escolar } & \text { Padre } \\
\text { Dantas } & & \end{array}$ & $\begin{array}{l}\text { Em funcionamento em } 1940 \\
\text { (narrativa da professora } \\
\text { Sônia de Souza Maynart) }\end{array}$ \\
\hline 27. Muribeca & $\begin{array}{l}\text { Grupo Escolar Rural (não } \\
\text { nomeado na mensagem } \\
\text { analisada) }\end{array}$ & $\begin{array}{l}\text { Em fase de conclusão } \\
\text { (mensagem de 1953) }\end{array}$ \\
\hline $\begin{array}{l}\text { 28. Nossa Senhora } \\
\text { das Dores }\end{array}$ & $\begin{array}{lrr}\text { Grupo } & \text { Escolar } & \text { Rural } \\
\text { General Calasans } & \end{array}$ & $\begin{array}{l}\text { Construído } \text { (mensagem de } \\
1950 \text { ) } \\
\text { Em funcionamento } \\
\text { (mensagem de 1953) }\end{array}$ \\
\hline $\begin{array}{l}\text { 29. Nossa Senhora } \\
\text { da Glória }\end{array}$ & \begin{tabular}{lll} 
Grupo & \multicolumn{2}{c}{ Escolar (não } \\
nomeado na mensagem
\end{tabular} & $\begin{array}{l}\text { Em funcionamento } \\
\text { (mensagem de 1954) }\end{array}$ \\
\hline
\end{tabular}




\begin{tabular}{|c|c|c|}
\hline & analisada) & \\
\hline 30. Neópolis & $\begin{array}{l}\text { Grupo Escolar Olympio } \\
\text { Campos }\end{array}$ & $\begin{array}{l}\text { Em funcionamento } \\
\text { (mensagem de 1930) }\end{array}$ \\
\hline 31. Propriá & $\begin{array}{lcl}\text { Grupo } & \text { Escolar } & \text { João } \\
\text { Fernandes de Brito } & \\
\end{array}$ & $\begin{array}{l}\text { Em funcionamento } \\
\text { (mensagem de 1930) }\end{array}$ \\
\hline 32. Propriá & $\begin{array}{lll}\text { Grupo } & \text { Escolar } & \text { Rural } \\
\text { Graccho } & \text { Cardoso } & \end{array}$ & $\begin{array}{l}\text { Em construção (mensagem } \\
\text { de 1951) } \\
\text { Em funcionamento } \\
\text { (mensagem de 1953) }\end{array}$ \\
\hline $\begin{array}{l}\text { 33. Riachão } \\
\text { Dantas }\end{array}$ & $\begin{array}{l}\text { Grupo Escolar } \\
\text { Lorival Fontes }\end{array}$ & $\begin{array}{ll}\text { Em } & \text { construção } \\
\text { (mensagem de 1954) }\end{array}$ \\
\hline 34. Riachuelo & $\begin{array}{l}\text { Grupo Escolar Francisco } \\
\text { Leite }\end{array}$ & $\begin{array}{l}\text { Aparece na mensagem de } \\
1936\end{array}$ \\
\hline 35. Ribeirópolis & $\begin{array}{lcc}\text { Grupo } & \text { Escolar } & \text { Rural } \\
\text { Abdias } & \text { Bezerra }\end{array}$ & $\begin{array}{l}\text { Em construção (mensagem } \\
\text { de 1951) } \\
\text { Em funcionamento } \\
\text { (mensagem de 1953) }\end{array}$ \\
\hline 36. Rosário do Catete & $\begin{array}{l}\text { Grupo Escolar Leandro } \\
\text { Maciel }\end{array}$ & $\begin{array}{l}\text { Obras públicas (mensagem } \\
\text { de 1952) }\end{array}$ \\
\hline 37.Salgado & $\begin{array}{l}\text { Grupo Escolar Rural } \\
\text { Alencar Cardoso }\end{array}$ & $\begin{array}{l}\text { Em funcionamento } \\
\text { (mensagem de 1954) }\end{array}$ \\
\hline $\begin{array}{l}\text { 38.Santa Luzia do } \\
\text { Itanhy }\end{array}$ & $\begin{array}{l}\text { Grupo Escolar Rural } \\
\text { Comendador Calazans }\end{array}$ & $\begin{array}{l}\text { Em fase de conclusão } \\
\text { (mensagem de 1953) }\end{array}$ \\
\hline $\begin{array}{l}\text { 39. Santa Rosa de } \\
\text { Lima }\end{array}$ & $\begin{array}{l}\text { Grupo Escolar Dr. Eldézio } \\
\text { Vieira de Melo }\end{array}$ & $\begin{array}{l}\text { Entregue (mensagem de } \\
\text { 1959) }\end{array}$ \\
\hline 40.São Cristóvão & $\begin{array}{l}\text { Grupo Escolar Vigário } \\
\text { Barroso }\end{array}$ & $\begin{array}{l}\text { Em funcionamento } \\
\text { (mensagem de 1930) }\end{array}$ \\
\hline 41.Simão Dias & $\begin{array}{l}\text { Grupo Escolar Fausto } \\
\text { Cardoso }\end{array}$ & $\begin{array}{l}\text { Em funcionamento } \\
\text { (mensagem de } 1930 \text { ) }\end{array}$ \\
\hline 42. Siriri & $\begin{array}{l}\text { Grupo Escolar José } \\
\text { Joaquim Barbosa }\end{array}$ & $\begin{array}{l}\text { Em funcionamento } \\
\text { (mensagem de 1954) }\end{array}$ \\
\hline 43.Tobias Barreto & $\begin{array}{l}\text { Grupo Escolar Tobias } \\
\text { Barreto }\end{array}$ & $\begin{array}{lll}\text { Construído (Relatório } & \text { da } \\
\text { Instrução Pública, 1943) } & \end{array}$ \\
\hline
\end{tabular}

Fonte: Quadro elaborado a partir das Mensagens de governadores do Estado de Sergipe emitidas entre os anos de 1930-1960.

O quadro anterior reúne os grupos escolares relacionados nas mensagens de governadores, relatórios de diretores da instrução pública, lista de escolas primárias emitidas pelo Departamento de Educação e narrativas de professores tomadas neste trabalho como fontes. A partir de tais documentos encontramos 43 grupos escolares "construídos" por todo estado de Sergipe, entre os anos 1930 e 1960. Dentre eles, quatro grupos escolares na região centro-sul e seis grupos no território do sul. Entretanto, em mensagem emitida pelo então governador Luiz Garcia, no ano de 1960, 
na qual faz um apanhado do número de grupos escolares existentes no estado, ficou evidente que Sergipe contava com "25 grupos escolares e 15 grupos escolares rurais", ou seja, 40 grupos escolares. Como pode ser notados no Quadro 1, 43 grupos foram revelados pelas mensagens, sendo que 27 são grupos escolares e 16 grupos escolares rurais. Esta incongruência talvez possa ser explicada pelo fato de 3 dos grupos elencados terem deixado de funcionar antes do ano de 1960, justificando, assim, a soma de 40 grupos. Diante disso, houve um maior cuidado com a quantidade de grupos escolares identificados, bem como com a forma de cruzar estas informações com as apresentadas por outros documentos, a exemplo do relatório da instrução pública, emitido pelo então Diretor José Rollemberg Leite, em 1943.

No referido relatório da instrução pública, assim como na lista de escolas rurais emitidas pelo Departamento de Educação do estado, em 1951, constam dois grupos escolares que não foram citados nas mensagens analisadas. Trata-se dos Grupos Escolares Senador Gonçalo Rollemberg, na cidade de Japaratuba, e Padre Dantas, em Maruim, este último revelado também pela narrativa da professora Sônia de Souza Maynart, disponível no acervo do projeto Memória Oral da Educação Sergipana. Pari passu às divergências, os documentos de Legalização educacional encontrados na Inspeção escolar do estado revelaram o funcionamento de dois grupos escolares, um na cidade de Siriri e outro na cidade de Nossa Senhora da Glória, esses não identificados nas listas de escolas primárias do Departamento de Educação.

Assim como os discursos pronunciados por Diretores da Instrução pública ou por governadores de Estado, as narrativas de professores também são carregadas de intenções que, apesar de distintas, não deixam de expressar um objetivo. Enquanto os primeiros podem representar uma preocupação voluntária das classes, dos grupos, dos indivíduos que dominaram e dominam as sociedades históricas em tornarem-se senhores da memória e do esquecimento (LE GOFF, 1990), o segundo imprime na história narrada, de forma voluntária ou involuntária, um passado concebido 
por quem o viveu, o que inclui a escolha de determinados fatos em detrimento de outros por motivos particulares que, muitas vezes, não são revelados em narrativa. "A lembrança é, em longa medida, uma reconstrução do passado com a ajuda de dados emprestados do presente, e onde a imagem de outrora se manifestou já bem alterada" (HALBWACHS, 2004 , p. 24.) Assim, tanto os documentos oficiais quanto a memória sugerem mais que afirmam, o que obriga o pesquisador a uma interpretação cautelosa. Mas como, das possíveis lembranças, dos lapsos, dos esquecimentos, dos silêncios e das intenções podemos apreender o real? Chartier (1990, p.80) sugere que o que é "lícito designar como realidade" provém da articulação dos regimes de prática e das séries de discursos.

Ao tentarmos entender as escolas primárias como objeto da História da Educação, articulamos os lapsos, as reconstruções e as representações dos entrevistados aos vestígios deixados pelos documentos oficiais. Como resultado dos "regimes de práticas e dos discursos" foi encontrado um campo de embate, onde as fontes constantemente se tencionavam, ora aproximando-se, ora afastando-se, mas sempre revelando particularidades que enriqueciam, ainda mais, a trama histórica da educação sergipana. Foi neste cenário de conflito que os nomes rememorados das escolas foram unidos/confrontados com os nomes dessas mesmas escolas dispostas nos documentos oficiais. Assim, desta junção, resultou o quadro a seguir:

Quadro 2 - Escolas apresentadas nas entrevistas identificadas por meio das lembranças e dos documentos oficiais (1930-1960)

\begin{tabular}{|l|l|l|}
\hline $\begin{array}{l}\text { NOME DE ESCOLAS (NARRATIVAS) } \\
\text { 1930-1960 }\end{array}$ & $\begin{array}{l}\text { NOME DE ESCOLAS (DOCUMENTOS } \\
\text { OFICIAIS) }\end{array}$ \\
\hline $\begin{array}{l}\text { 1. Escola da professora Carmita Moreira } \\
\text { na cidade de Salgado (Acinete } \\
\text { Almeida Bispo, 2012) }\end{array}$ & $\begin{array}{l}\text { Escola isolada No 01 (controle do } \\
\text { movimento mensal - 1951) }\end{array}$ \\
\hline $\begin{array}{l}\text { 2. Escola Municipal Doutor Josias } \\
\text { Machado na cidade de Lagarto (Ana } \\
\text { Rodrigues de Menezes, 2012) }\end{array}$ & $\begin{array}{l}\text { Escola Dr. Josias Machado (controle do } \\
\text { movimento escolar - 1952) }\end{array}$ \\
\hline 3. Grupo Escolar Sylvio Romero na & Grupo Escolar Sylvio Romero (Relação \\
\hline
\end{tabular}




\begin{tabular}{|c|c|}
\hline $\begin{array}{l}\text { cidade de Lagarto (Ana Rodrigues de } \\
\text { Menezes, 2012) }\end{array}$ & de escolas primárias - 193 \\
\hline $\begin{array}{l}\text { 4. Colégio Sagrado Coração de Jesus na } \\
\text { cidade de Estância (Cordélia do } \\
\text { Nascimento Costa, 2011) }\end{array}$ & $\begin{array}{l}\text { Colégio Sagrado Coração de Jesus } \\
\text { (Departamento de Educação, 1938) }\end{array}$ \\
\hline $\begin{array}{l}\text { 5. Escola Municipal da professora Zena } \\
\text { Alves da Costa na cidade de Indiaroba } \\
\text { (Josefa Maria da Conceição, 2011) }\end{array}$ & $\begin{array}{l}\text { Estabelecimento de Ensino público } \\
\text { municipal- São José. Prof.a Zena Alves } \\
\text { da Costa (Departamento de Educação, } \\
\text { 1938) }\end{array}$ \\
\hline $\begin{array}{l}\text { 6. Escola Isolada No } 1 \text { na cidade de } \\
\text { Arauá (Janice Santos Silva, 2011) }\end{array}$ & $\begin{array}{llll}\text { Escola Isolada do sexo feminino } \\
\text { Número } 1 \text { (Termo de inspeção 1944) }\end{array}$ \\
\hline $\begin{array}{l}\text { 7. Banca Escolar na cidade de Arauá } \\
\text { (Janice Santos Silva, 2011) }\end{array}$ & $\begin{array}{l}\text { Não foi encontrada nos documentos } \\
\text { analisados nenhuma referência sobre } \\
\text { esta escola primária. }\end{array}$ \\
\hline $\begin{array}{l}\text { 8. Escola municipal Maria Cotias Sales na } \\
\text { cidade de Tomar do Geru (José Walter } \\
\text { Leonidio da Silva, 2011) }\end{array}$ & $\begin{array}{l}\text { Não foi encontrada nos documentos } \\
\text { analisados nenhuma referência sobre } \\
\text { esta escola primária. }\end{array}$ \\
\hline $\begin{array}{l}\text { 9. Instituto Estanciano de Ensino } \\
\text { professor Azarias Alves dos Santos na } \\
\text { cidade de Estância (Josefa Maria da } \\
\text { Conceição, 2011) }\end{array}$ & $\begin{array}{llr}\text { Colégio } & \text { Esperança (prof. Azarias } \\
\text { Santos) } & \text { (Departamento de Educação, } \\
1938) & \end{array}$ \\
\hline $\begin{array}{l}\text { 10. Escola Estadual do povoado Várzea } \\
\text { dos Cágados na cidade de Lagarto } \\
\text { (Josefa Santana da Silva, 2012) }\end{array}$ & $\begin{array}{l}\text { Escola Isolada s/n (Termo de inspeção - } \\
\text { 1944) }\end{array}$ \\
\hline $\begin{array}{l}\text { 11. Escola pública N03 na cidade de Tomar } \\
\text { do Geru (Lindinalva Oliveira de } \\
\text { Santana, 2011) }\end{array}$ & $\begin{array}{l}\text { Não foi encontrada nos documentos } \\
\text { analisados nenhuma referência sobre } \\
\text { esta escola primária. }\end{array}$ \\
\hline $\begin{array}{l}\text { 12. Grêmio Escolar Serrano na cidade de } \\
\text { Itabaianinha (Rivanda Alves de } \\
\text { Oliveira Cabral, 2011) }\end{array}$ & $\begin{array}{l}\text { Grêmio Escolar Serrano (Termos de } \\
\text { Inspeção- 1944) }\end{array}$ \\
\hline $\begin{array}{l}\text { 13. Escola da Fazenda Flor do Rio na } \\
\text { cidade de Pedrinhas (Maria dos } \\
\text { Santos Santana, 2011) }\end{array}$ & $\begin{array}{l}\text { Não foi encontrada nos documentos } \\
\text { analisados nenhuma referência sobre } \\
\text { esta escola primária. }\end{array}$ \\
\hline $\begin{array}{l}\text { 14. Escola pública No } 1 \text { na cidade de } \\
\text { Itabaianinha (Maria do Carmo Fontes } \\
\text { Silva, 2012) }\end{array}$ & $\begin{array}{l}\text { Escola Pública Primária Isolada do sexo } \\
\text { feminino da cidade de Itabaianinha } \\
\text { (Ponto diário - 1935) }\end{array}$ \\
\hline $\begin{array}{l}\text { 15. Escolas reunidas Augusto Maynard na } \\
\text { cidade de Simão Dias (Olda do Prado } \\
\text { Dantas, 2012) }\end{array}$ & $\begin{array}{l}\text { Escolas reunidas Augusto Maynard } \\
\text { (Departamento de Educação, 1938) }\end{array}$ \\
\hline $\begin{array}{l}\text { 16. Grupo Escolar Fausto Cardoso na } \\
\text { cidade de Simão Dias (Olda do Prado } \\
\text { Dantas, 2012) }\end{array}$ & $\begin{array}{l}\text { Grupo Escolar Fausto Cardoso (Termos } \\
\text { de inspeção - 1944) }\end{array}$ \\
\hline $\begin{array}{l}\text { 17. Escola da fazenda Paiaiá na cidade de } \\
\text { Cristinápolis (Maria Lita Silveira, } \\
\text { 2011) }\end{array}$ & $\begin{array}{l}\text { Não foi encontrada nos documentos } \\
\text { analisados nenhuma referência sobre } \\
\text { esta escola primária. }\end{array}$ \\
\hline $\begin{array}{l}\text { 18. Escola Isolada Soldadinho de Chumbo } \\
\text { na cidade de Umbaúba (Josefina } \\
\text { Batista Hora, 2011) }\end{array}$ & $\begin{array}{l}\text { Grupo Escolar Dr. Antonio Garcia Filho } \\
\text { (Dissertação de Mestrado intitulada } \\
\text { Memórias de educadoras sergipanas: } \\
\text { práticas escolares e cultura escolar no } \\
\text { município de Umbaúba/SE (1955 - } \\
\text { 1989) }\end{array}$ \\
\hline
\end{tabular}




\begin{tabular}{|l|l|l|}
\hline $\begin{array}{l}\text { 19. Escola da Fazenda Lagoa de Dentro } \\
\text { na cidade de Arauá (Laudiceia } \\
\text { Rodrigues Cerqueira, 2011) }\end{array}$ & $\begin{array}{l}\text { Não foi encontrada nos documentos } \\
\text { analisados nenhuma referência sobre } \\
\text { esta escola primária. }\end{array}$ \\
\hline $\begin{array}{l}\text { 20. Escola particular na cidade de Simão } \\
\text { Dias (Raimunda Alves dos Santos, } \\
\text { 2012) }\end{array}$ & $\begin{array}{l}\text { Não foi encontrada nos documentos } \\
\text { analisados nenhuma referência sobre } \\
\text { esta escola primária. }\end{array}$ \\
\hline $\begin{array}{l}\text { 21. Banca escolar da professora Eurides } \\
\text { na cidade de Itabaianinha (Maria } \\
\text { Eurides da Silva, 2011) }\end{array}$ & $\begin{array}{l}\text { Não foi encontrada nos documentos } \\
\text { analisados nenhuma referência sobre } \\
\text { esta escola primária. }\end{array}$ \\
\hline $\begin{array}{l}\text { 22. Escola Estadual Rural do Povoado } \\
\text { Água Fria na cidade de Salgado (Luzia } \\
\text { Honória dos Santos, 2011) }\end{array}$ & $\begin{array}{l}\text { Escola Rural Água Fria (termo de } \\
\text { inspeção 1949) }\end{array}$ \\
\hline $\begin{array}{l}\text { 23. Escola Particular da professora Lurdes } \\
\text { Souza na cidade de Arauá (Laudiceia } \\
\text { Rodrigues Cerqueira, 2011) }\end{array}$ & $\begin{array}{l}\text { Escola Particular Progresso (termo de } \\
\text { inspeção 1944) }\end{array}$ \\
\hline $\begin{array}{l}\text { 24. Grupo Escolar Manoel Bonfim na } \\
\text { cidade de Arauá (Laudiceia Rodrigues } \\
\text { Cerqueira, 2011) }\end{array}$ & $\begin{array}{l}\text { Grupo Escolar Rural Manoel Bonfim } \\
\text { (Relação de escolas em 1955) }\end{array}$ \\
\hline $\begin{array}{l}\text { 25. Grupo Escolar Tobias Barreto na } \\
\text { cidade de Tobias Barreto (Maria } \\
\text { Auxiliadora Oliveira, 2015) }\end{array}$ & $\begin{array}{l}\text { Grupo Escolar } \\
\text { (Relatório da Instrução Pública - 1943) }\end{array}$ \\
\hline $\begin{array}{l}\text { 26. Escola da Aviação Férrea Federal } \\
\text { Leste Brasileira na cidade de Boquim } \\
\text { (Antônio Barros Vasconcelos, 2011) }\end{array}$ & Não foi encontrada nenhuma referência \\
nos documentos estudados
\end{tabular}

Fonte: Quadro elaborado pelas autoras a partir das 29 entrevistas.

Não foi possível realizar um diálogo harmonioso entre os documentos oficiais e as lembranças dos entrevistados. Como pode ser observado no Quadro 2, muitas escolas primárias dadas a ver pelas narrativas não foram encontradas nos Relatórios de inspetores, nas Relações de escolas primárias 
do estado, nos "controles de movimento escolar" e nos "pontos diários" mapeados. O constante confronto entre as lembranças e os documentos oficiais nos levou a criar estratégias de pesquisa para realizar um trabalho de identificação que pudesse partir de esquecimentos e intenções diversas. Além de situar, geográfica e historicamente, as escolas presentes nas narrativas, muitas vezes foi necessário nos valer de pistas envolvendo nomes de professores e datas para encontrar, nos documentos oficiais, tais escolas. Isso porque, na maioria das vezes, seus nomes não eram lembrados exatamente como foram ou deveriam ter sido, pelo menos oficialmente.

Sem arriscar propor respostas, seguimos levando por todo o trabalho as variadas e supostas intenções das fontes, bem como as diversas maneiras de se compreender os fatos. É possível que esta pluralidade de sentidos possa agregar características particulares à História da escola primária sergipana na medida em que os encontros e desencontros entre documento oficial e memória, como pode ser identificado no Quadro 2, começam a delinear o cenário das escolas primárias do centro e sul sergipanos no referido tempo, este composto de grupos escolares, escolas isoladas, escolas particulares, escolas reunidas, bancas escolares e escolas da fazenda. Assim, foi por meio das vivências dos entrevistados que foram evidenciados tipos de escolas não destacados no discurso político, haja vista sua precariedade física e material, seu funcionamento em dois turnos envolvendo uma única professora e suas turmas lotadas de alunos.

Sobre a existência das escolas isoladas, escolas reunidas e dos grupos escolares, a professora Olda do Prado Dantas lembrou-se do tempo em que foi aluna e professora nesses tipos de escolas, presentes na cidade de Simão Dias desde a década de 1920. Aos cento e três anos de idade, a professora Olda ainda lembrou que foi na sua própria casa, a qual funcionava como uma escola isolada do município, tendo sua mãe como professora, que aprendeu as primeiras letras. Terminado o primário ingressou, em 1925, no curso normal do Instituto Ponte Nova no estado da 
Bahia $^{9}$, retornando à cidade natal, em 1934. Logo que terminou o curso normal, "o doutor Marcos Ferreira reuniu as escolas das casas e botou em um prédio só". A esta escola chamou-se Escolas Reunidas Augusto Maynard, onde a professora Olda passou a lecionar a partir do ano de 1934. Quatro anos depois passou a ser professora no Grupo Escolar Fausto Cardoso, na cidade de Simão Dias, onde permaneceu até a sua aposentadoria na década de 1960 .

Além das escolas particulares foi evidente, nas narrativas analisadas, a presença das bancas escolares e escolas das fazendas, ambas de iniciativas privadas. Estas eram espaços precários onde o ensino do ler, escrever e contar, se fazia por meio de planos de aulas organizados a partir dos saberes do professor. Segundo Santos e Silva (2012), as bancas escolares podem ser entendidas como "[...] uma educação doméstica, de iniciativa particular, sem qualquer vínculo com o poder público e que usava como mobiliário e espaço escolar os móveis e a casa da professora" (SANTOS; SILVA; 2012, s/p). A banca escolar da professora Janice Santos Silva, na cidade de Arauá, por exemplo, tinha o papel de reforçar os assuntos apreendidos na escola primária "oficial", onde o aluno estudava em turno contrário ao da banca escolar. Já a banca escolar da professora Maria Eurides da Silva, na cidade de Itabaianinha, era considerada pela professora como "uma escola", pois o "aluno entrava no Abc e saía na terceira, quarta série. Só iam para o Grupo tirar o diploma". Sua banca escolar, como uma instituição educacional, que ofertava o ensino elementar,

[...] permitiu, para além da apropriação dos conteúdos das matérias escolares, inculcar comportamentos e condutas reconhecidas e aceitas por todos os que, direta ou indiretamente, privaram de seus ensinamentos. Quando seus alunos iam para o "grupo" apenas tirar o diploma, ela nos mostra que o município, em nome da prefeitura e dos grupos escolares que já existiam na época, legitimava a educação que ela ofertava, no momento em que concedia o diploma de conclusão do primário, permitindo, assim, o ingresso do seu

${ }^{9}$ O Instituto Ponte Nova , localizado na cidade de Wagner/BA, está situado a $529 \mathrm{~km}$ de distância da cidade de Simão Dias. 
aluno no curso ginasial (BARRETO; MESQUITA; SANTOS, 2015, p. 258).

As escolas da fazenda também podem ser consideradas de iniciativa particular se levarmos em consideração que cobrar uma quantia para, em sua própria residência, ofertar o ensino primário, seria uma tática de viabilizar o ensino. Na Escola da Fazenda Flor do Rio, localizada na cidade de Pedrinhas, por exemplo, onde a professora Maria Santos Santana cursou parte do ensino primário, em 1945, era necessário pagar uma quantia de "cinco mil reis" para estudar. Na Escola da Fazenda Lagoa de Dentro, onde a professora Laudicéia Rodrigues Cerqueira começou a sua carreira como docente, em meados do século XX, na cidade de Arauá, seus alunos "eram os filhos dos fazendeiros". Havia uma relação estreita entre ela, enquanto professora, e os pais dos alunos, pois, como lembra: "o dono da fazenda me arranjou umas cadeiras [...] e a esposa dele, a dona da fazenda, comprou livros para os filhos e comprou para os que não eram filhos".

Sejam escolas da fazenda, escolas domésticas ou bancas escolares, o que chamou a atenção foram as diferentes configurações com que a iniciativa particular, presente em todas elas, se caracterizou. Seja partindo dos pais dos alunos, ou de um fazendeiro, o que se pode considerar é que há evidências de que no centro e sul do estado de Sergipe existiram escolas primárias de iniciativas particulares sediadas em prédios impróprios, com professores não formados e com ausência de fiscalização governamental, requisitos que, por lei, deveriam ser cumpridos. Assim, por estarem à revelia dos critérios estabelecidos por atos normativos, tais escolas de iniciativa particular funcionavam, mas não faziam parte das escolas particulares apresentadas nas listas de escolas primárias de todo o estado. A partir desta premissa, se elas não eram consideradas, oficialmente, como particulares e, também, não eram escolas públicas, pois partiam da iniciativa privada, em qual modalidade elas podem ser enquadradas?

Seja qual for a modalidade, o fato é que, segundo as narrativas, havia possibilidades para que as escolas de iniciativa pessoal pudessem se tornar públicas. Sobre isso, a professora Lindinalva Oliveira de Santana, residente 
na cidade de Tomar do Geru, lembra que o município realizou esforços para incluir a sua escola doméstica, a princípio criada e mantida pela professora e pelos pais dos alunos em sua residência, no quadro de escolas públicas. A entrevistada lembra que, por volta do ano de 1957, os pais dos alunos foram na sua casa pedir para que ela abrisse uma escola. Assustada com o pedido, ela lembra que se indagou: "- Como vou abrir essa escola se não tem colégio [espaço] aqui?" Os pais então sugeriram que ela usasse o "salãozinho" que tinha na sua casa. Depois de "falar com seu esposo", decidiu aceitar. Com a ajuda dos pais dos alunos ela começou a materializar sua escola. O primeiro passo foi procurar um "carpinteiro" para que com "os pedacinhos de pau [madeira] que ele tivesse, pudessem ser feitos os acentos e as tabuas para os alunos colocarem no colo e fazerem uma banquinha para escrever". Após três anos "ensinando dessa forma", a professora Lindinalva realizou um "teste" para ingressar no quadro de professoras primárias do município. Logo que foi aprovada, a professora Lindinalva lembra que:

\begin{abstract}
Na segunda-feira minha filha, agora aí encheu a casa! As mães inventaram assim, vai entrar o mês de maio, nós vamos fazer novenas com leilões para arrumar alguma quantia pra nós comprar [sic.] bancos, mesas, tudo que for necessário. Aí as mães se juntaram, se reuniram pra comprar cadeiras, bancos, mesa, mandou fazer quadros que a prefeitura não disponibilizava. Depois chegou a merenda, aí eu tinha que ser professora e merendeira. E vinha pegar aqui ainda [sede da cidade de Tomar do Geru], nem mandar pra lá não vinha não. Nesse tempo quem era a coordenadora, a supervisora, diretora eram as de Estância [sic]. Quando a gente pensava que não, olhava um jipe! Era de jipe que elas vinham para assistir, na hora da merenda, se aquela merenda estava competente para as crianças. Eu digo, olha! ali vem a fiscalização!. Na hora que ela chegar aqui vocês levantem e saúdem elas. Mesmo ensinando pelo município eu dava aulas dentro de casa. Dentro da minha casa ainda trabalhei para o município 17 anos (Lindinalva Oliveira de Santana, 2011).
\end{abstract}

As lembranças da professora Lindinalva indiciam que, ao se tornar professora do município, a sua escola de iniciativa particular, que atendia a um número considerável de alunos ao mesmo tempo em que funcionava em 
uma localidade onde não existiam outros tipos de escolas, passou a ser subsidiada e fiscalizada pelo município. Mesmo em condições físicas e materiais precárias, pois utilizava como espaço um cômodo da casa da professora e mobília fruto de "leilões e novenas" organizadas pelos pais dos alunos, a escola de iniciativa pessoal da professora Lindinalva passou a ser reconhecida, logo após a sua contratação, como "escola do município".

Assim como as narrativas de história de vida (temática) revelaram tipos de escolas não ideais, elas também indiciam as mudanças e adaptações ocorridas no cenário escolar a partir, nesse estudo, de meados da década de 1940. Um fenômeno importante, e já sinalizado, é que a fim de "aumentar a rede escolar no meio rural", o Instituto Nacional de Estudos Pedagógicos (Inep), ao constatar que, em 1945, "60\% da população do Brasil não era atingida pela rede escolar existente", e que tais condições "precárias provinham da falta de escolas rurais", pôs em prática um plano voltado para a expansão de escolas no meio rural. Em Sergipe, foi a partir do ano de 1947 que começaram a ser implantados grupos escolares rurais, escolas normais rurais e escolas rurais, o que fez com que tais escolas ganhassem destaque nos discursos políticos e nas memórias de professores nesse período.

\section{Discursos oficiais e narrativas de professores: em destaque as escolas rurais (1948-1960)}

Aumentar a rede escolar por meio das escolas rurais e dotar tais escolas de recursos materiais e professores capacitados serviram de plataforma política para o primeiro mandato do governador José Rollemberg Leite (1947-1951). As ações do então governador sergipano foram uma resposta ao plano de expansão das escolas primárias elaborado pelo Inep, que esteve entre os anos de 1947 e 1951 sob a direção de Murilo Braga de Carvalho. Ao revelar em seu discurso que "[...] já se deu demais à cidade; é preciso cuidar, agora, do interior", o diretor do Inep mostrava que a expansão das escolas primárias seguiria em direção ao rural. Segundo ele, do convênio que poderia ser estabelecido entre Estados e Inep, para 
construção de escolas rurais, poderia resultar, no ano de 1951, um montante de "[...] oito mil prédios escolares erguidos pelo 'hinterland', podendo aí se localizarem, por ano, 800 mil crianças para receber instrução, que vai desde o ensino das primeiras letras a rudimentos de agricultura" (INSTITUTO... 1950, p. 175).

No processo de expansão das escolas rurais, o estado de Sergipe teve um papel de destaque, pois serviu de laboratório para as observações e impressões sobre o ensino rural no Brasil que alicerçariam o Seminário de Educação Rural, promovido pelo Inep, em 1950. Assim, o trabalho de construção foi "[...] se desenvolvendo com muita celeridade, o que tem colocado [Sergipe] na vanguarda dos que, em todo o país, recebem, agradecidos, a importante colaboração do Governo Federal" (SERGIPE, 1949, p. XIII.). Esta suposta agilidade teve a intenção de ampliar a rede de ensino primário de três tipos de escolas rurais: os grupos escolares rurais, as escolas normais rurais e as escolas típicas rurais.

Iniciada no ano de 1947, tal política de ampliação teve para o governo de José Rollemberg Leite (1947-1951) "[...] créditos especiais abertos para a construção de Escolas Rurais, tendo como receita o auxílio especial concedido pelo Inep" (SERGIPE, 1948, p. 27). Segundo o governador, no ano de 1947, 18 escolas estavam construídas e 27 em construção, tudo no valor de Cr\$1.864.000,00. Já para o ano de 1948 quase $\operatorname{Cr} \$ 2.000 .000,00$ dos $\operatorname{Cr} \$ 4.276 .878,00$ destinados a despesas por créditos especiais, foram para construção das escolas rurais e para o ensino supletivo (SERGIPE, 1948).

Os governos que sucederam o mandato de José Rollemberg Leite também receberam auxílio do Inep para a expansão das escolas primárias. Contudo, há que se considerar, como revelou o governador Arnaldo Rollemberg Garcez, em 1952, que "a maior diminuição de despesas registrou-se no setor da Educação Pública, o que se explica pelo fato de haver diminuído em 1951, o volume de auxílios federais para construção de edifícios escolares" (SERGIPE, 1952, p. 95). Deste modo, a construção das 218 escolas rurais e 10 grupos escolares rurais no governo de José 
Rollemberg Leite, que representa a maior expansão, em termos quantitativos, dentre os governos de 1947 e 1960, pode ser justificada, principalmente, pelos créditos cedidos pelo Inep. Embora houvesse esses "auxílios generosos", o governador deixou claro que mesmo com os investimentos federais, caberia ao estado a responsabilidade por arcar com despesas advindas de contratação de funcionários e aparelhamento das escolas (SERGIPE, 1951), fato que pode ter sido responsável por muitas das escolas rurais, em especial os grupos escolares, terem sido iniciados em um governo e inauguradas em outro. Como exemplo disso estão quatro dos dez grupos escolares construídos no governo de José Rollemberg Leite.

Os grupos escolares das cidades de "Propriá, Ribeirópolis, Darcilena ${ }^{10} \mathrm{e}$ Arauá", que em 1951 estavam em construção, só constam oficialmente como inaugurados no ano de 1953, no então governo de Arnaldo Rollemberg Garcez. No mesmo ano, o governador deu início à construção de mais dois grupos escolares nas cidades de Santa Luzia do Itanhy e Muribeca e inaugurou o Grupo Escolar Ivo do Prado na capital Aracaju, que também foi construído no governo de José Rollemberg Leite. Assim, em 1954, o estado de Sergipe contava:

[...] com duzentos e quarenta e seis (246) Escolas e dezessete $(17)^{11}$ grupos deste tipo. Estão os últimos localizados em Aracaju, Propriá, Nossa Senhora das Dores, Frei Paulo, Itabaianinha, Japoatã, Itaporanga d'Ajuda, Campo do Brito, Darcilena, Ribeirópolis, Arauá, Santa Luzia do Itanhy, Gararu, Salgado, Siriri e Nossa Senhora da Glória, todos devidamente mobiliados (SERGIPE, 1954, p. 24).

As expectativas para construção dos grupos escolares no governo de Arnaldo Rollemberg Garcez foram superadas, uma vez que, além de se cumprir o que se tinha esperado para o ano de 1954, que era a inauguração de dois grupos rurais nas cidades de Santa Luzia do Itanhy e Muribeca,

\footnotetext{
${ }^{10}$ Atual Cedro de São João.

${ }^{11}$ Apesar de ter sido anunciado 17 grupos, apenas 16 foram elencados, talvez por um erro de digitação não comtemplaram a cidade de Muribeca. Há evidências de que foi construído um grupo escolar nessa cidade, pois ele é citado na mensagem de 1954, no conteúdo referente ao Departamento de obras públicas, como um grupo escolar construído com a quantia de Cr\$ $198.000,00$.
} 
foram construídos no mesmo ano mais quatro, distribuídos pelas cidades de Gararu, Salgado, Siriri, Nossa Senhora da Glória. Esta agilidade, não encontrada nos governos anteriores e posteriores, nem mesmo nos outros anos do seu governo, levantou o seguinte questionamento: quais foram os fatores que contribuíram para que em um ano fossem construídos e/ou inaugurados cinco grupos escolares? O que chama atenção não é a quantidade, até porque no governo anterior foram construídos, em quatro anos, dez grupos escolares e 218 escolas rurais, mas a celeridade da construção entre os anos de 1953 e 1954. Talvez a resposta para esta inquietação possa estar em maiores investimentos econômicos nesse ano, atrelados a metas estabelecidas pelo governo federal para os estados. Assim, estando Arnaldo Rollemberg Garcez em seu último ano de mandato, acelerou a construção de grupos escolares, em detrimento das escolas rurais que já tinham sido potencializadas no governo anterior, a fim de cumprir uma possível cota exigida.

De modo que fosse pela diminuição dos investimentos federais, fosse pela falta de recursos para aparelhar e, assim, pôr em funcionamento as escolas já construídas, o fato é que pouco se avançou quantitativamente, comparado aos anos anteriores, no número de escolas rurais entre 1952 e 1960. Sobre o seu governo, Leandro Maciel (1955-1958) considerou que "[...] o ensino rural em nosso estado, durante o ano [1956], não obteve o resultado que se poderia esperar dessa forma de educação" (MACIEL, 1956, p. 64). Além disso, o governador considerou que "[...] o dever para com o ensino não estará cumprido apenas com a instalação de escolas destinadas à infância. Há o dever de proporcionar educação aos adultos, na obra de reconstrução social, tão recomendada pelos ideais cristãos" (MACIEL, 1956, p. 61). Tal discurso, que a princípio parece destoar das palavras promissoras e esperançosas apresentadas nas mensagens dos governos anteriores, é justificado por Leandro Maciel pelos insistentes problemas financeiros, poucos professores para ensinar nas escolas rurais e a precariedade dos prédios escolares, este último responsável pela maioria dos investimentos feitos pelo departamento de obras públicas, em 1957. 
Segundo o governador Leandro Maciel, estes reparos foram essenciais para as escolas rurais, pois havia uma "[...] necessidade urgente de serem recuperados os prédios relegados ao abandono" (MACIEL, 1957, p. 64). Sobre as escolas rurais, que serviram de modelo, em 1953, para as observações feitas pelo professor King Hall ${ }^{12}$ a pedido do Inep, Leandro Maciel considerou:

A rede patrimonial das escolas rurais é de 248 unidades distribuídas pelos municípios sergipanos, mas, por incrível que pareça foram encontradas apenas 231 escolas... É um capítulo à margem de nossa história educacional o drama tortuoso da cristalização desse ensino na vida sergipana. Nem merece comentário a construção dessas escolas, por ser um fato que traz constrangimento. Essas escolas, para não ruírem todas, exigem reparos e consertos, como se reportou a respeito o Departamento de Obras (MACIEL, 1956, p. 64).

Tal discurso revela duas problemáticas. A primeira, diz respeito às condições em que estas escolas rurais funcionavam. Em relatório apresentado ao Inep, o diretor Murilo Braga, em 1950, apontou que pela simplicidade das escolas rurais seria possível revesti-las, se preciso fosse, para a maior e mais rápida construção e expansão, "[...] de tijolos, de adobe, de madeira e, se necessário fosse, até de pau a pique. Usaremos para cobertura, por exemplo, o material mais adequado pelo preço e pela facilidade de obtenção: toalha, eternite, palha ou sapé" (INSTITUTO NACIONAL DE ESTUDOS PEDAGÓGICOS, 1950, p. 171). Este relatório põe em questionamento a qualidade dos prédios escolares. Se eles deveriam ser construídos com celeridade, mesmo que para isso utilizassem os mais rudimentares materiais, é bem provável que eles não resistiriam ao tempo. Evidência disso são as constatações do governador Leandro Maciel, que para "não ruírem todas" voltou suas atenções para o reparo de muitas dessas escolas. Tais reformas, talvez possam justificar a construção de apenas duas escolas rurais durante todo seu governo. Trata-se dos grupos

12 Robert King Hall foi um pesquisador norte-americano especialista em Educação Comparada no Brasil entre as décadas de 1940 e 1950. No final dos anos 1940 colaborou com o Instituto Nacional de Estudos Pedagógicos (INEP) no projeto modelo para criação de escolas rurais no Brasil.

História \& Ensino, Londrina, v. 25, n. 1, p. 453-483, jan./jun. 2019 
nas cidades de Carira e Cumbe, concluídos em 1958. Entretanto, é imprescindível considerar, ainda, que o fato de terem sido construídas apenas duas escolas graduadas pode estar atrelado à relação de números de escolas rurais já existentes ou a metas possíveis no mandato. Segundo o governador, os problemas educacionais não eram "[...] apenas fatores de falta de aparelhamento ou de ordem política, [...] mas ocorrências mais profundas, que se louvem na nossa estrutura econômica, de função nitidamente colonial" (MACIEL, 1957, p. 61).

Todas as mensagens estudadas entre 1948 e 1960 registram uma matrícula geral do ensino primário, o que, por sua vez, dificulta que, por meio delas, possamos mensurar o número de matrícula de cada tipo de escola. Talvez este detalhamento não fosse tão importante no discurso oficial, afinal, segundo o que foi apresentado em relatório pelo professor King Hall, apesar das omissões e ausências, "[...] um fato incontestável permanece de pé: o plano produziu escolas" (INSTITUTO NACIONAL DE ESTUDOS PEDAGÓGICOS, 1950, p. 118). Como já preconizava o professor King Hall, no plano seguinte à sua avaliação houve um aumento significativo de escolas. Contudo, a preocupação com a qualidade dos prédios escolares de acordo, principalmente, com os discursos do governador Leandro Maciel, parece ter ficado em segundo plano. As preocupações, que ora se polarizam entre quantidade em detrimento da qualidade, sugerem reflexões sobre a proposta do programa de ensino rural desenvolvido em Sergipe com a ajuda do Inep e, por isso, surgem as indagações: a construção das centenas de escolas primárias rurais conseguiram levar e/ou produzir uma educação para o campo, e deste modo diminuir o número de analfabetos por todo Brasil?; podemos considerar que houve resultados positivos com a expansão do ensino primário rural?

No caso de Sergipe, na medida em que as escolas rurais se expandiam, outros tipos de escolas continuavam a funcionar, muitas vezes porque havia a necessidade de alfabetizar alunos em lugares onde não existiram escolas consideradas como ideais ou enquanto elas não fossem 
construídas, mas, também, porque havia uma predileção pelas escolas mais "antigas". Na cidade de Arauá, por exemplo, existia, em 1953, o Grupo Escolar Rural Manoel Bonfim e, na mesma cidade, uma Banca Escolar e uma Escola da Fazenda Lagoa de Dentro, ambas evidenciadas pelas narrativas das professoras Janice Santos Silva e Laudicéia Rodrigues Cerqueira, respectivamente. A presença destas últimas, não condizentes ao projeto republicano de ensino, não se justificava pela ausência do grupo escolar, mas, talvez, pelo fato de funcionarem nas casas dos professores, que eram mais próximas, em termos geográficos, dos alunos.

Fatores culturais e de construção de identidade que estavam atrelados à proximidade com o professor e com a aceitação da "nova/velha" escola, também podem ser levados em consideração. A entrevistada Rivanda de Oliveira Cabral (2011), ao lembrar da autoridade conferida a sua professora primária, "Dona Zizi", contribui para tal hipótese. Ela narrou que no Colégio Particular Grêmio Escolar Serrano, em meados do século passado, funcionava "[...] um esquema: tinha um corneteiro que quando dava nove horas... aí a corneta tocava (lalalalarilalalarilalalri). $O$ aluno que tivesse na rua nove horas, corria pra casa! Se um [aluno] ficasse e alguém avistasse, no outro dia dona Zizi ia saber". Em muitas das narrativas a professora foi concebida, sobretudo por quem a representava, como uma autoridade que desenvolvia, dentre outros papeis, o controle corporal além muro da escola e a imposição do tempo escolar no ritmo diário dos alunos, uma vez que sua presença era constante nas atividades extraescolares, como no "lanche da tarde" em família. O que nos leva a entender que, para além dos problemas próprios de implantação de um novo projeto, existia uma relação afetiva entre os sujeitos escolares e suas respectivas famílias, a qual pode ter contribuído para que o "novo/moderno projeto republicano de ensino" demorasse a ser efetivado.

Todos esses impasses de ordem econômica, cultural, afetiva, política, dentre outros, podem justificar a presença, em 1960, de 609 escolas isoladas e rurais; 25 grupos escolares; 15 grupos escolares rurais; e seis Escolas reunidas (SERGIPE, 1959). O montante de 609 escolas, o qual 
é dividido entre escolas rurais e isoladas, revela que as escolas rurais não atuavam sozinhas como atores principais na História das escolas primárias existentes entre os 1947 e 1960. Por certo, a quantidade de tais escolas está escamoteada pelas escolas rurais, e vice-versa. Contudo, sua presença revela que, em 1960, elas ainda contracenavam e, por este motivo, o processo de expansão das escolas primárias no estado de Sergipe, embora priorizasse os grupos escolares e seus similares, não pode deixar de computar essas escolas como elementos fundamentais no processo de escolarização. Do mesmo modo, as narrativas revelam que não só elas, mas as bancas escolares e as escolas das fazendas também fizeram parte das escolas primárias, ao menos das regiões do centro-sul e sul sergipanos. 0 que nos faz entender que, embora existisse um projeto nacional com objetivos louváveis, a escola primária foi se configurando a partir do que foi possível fazer dadas as condições financeiras, intelectuais, políticas e culturais dos sujeitos e instituições envolvidas em cada processo de expansão.

\section{Considerações Finais}

Por meio da (des)construção do prescrito e do rememorado, foi possível concluir que, ora em consonância, ora em desacordo com propostas educativas da época, diversos tipos de escolas primárias existiram no espaço e tempo estudados. O projeto de expansão, que tinha como instituições ideais os grupos escolares urbanos e as escolas rurais (a partir de 1947), foi implementado, embora escolas precárias em mobília e material didático, sem prédio próprio e com professores que começaram a atuar sem formação específica - como as escolas isoladas, das fazendas, de iniciativas particulares, bancas escolares - sobreviveram às propostas de mudanças e ao período.

Há que se considerar que privilegiar como objeto de estudo as escolas apresentadas por meio de 29 entrevistados é levar em consideração que as narrativas representam parte de um universo muito maior e mais complexo da História. Por isso, partimos do pressuposto de que elas não 
devem ser generalizadas nem no tempo, nem no espaço, embora permitam, assim como outro tipo de documento, adentrar na multiplicidade de elementos e de eventos que ajudam a compor parte da História, não necessariamente seu todo. O que aqui expusemos foi o seu potencial no tocante à compreensão dos tipos de escolas subordinados a uma configuração ditada pelos financiamentos e planos nacionais, mas, principalmente, pelas condições políticas, materiais, culturais e intelectuais dos atores que estiveram diretamente envolvidos na Educação.

A análise que privilegiou o cruzamento de documentos escritos e memórias de professores, por meio da abordagem da História vista de baixo, pode contribuir com uma nova perspectiva de entendimento de História e, consequentemente, do seu ensino. Estudos que levam em consideração sujeitos simples, também atores históricos, agregam aos livros didáticos e, consequentemente, ao Ensino de História, uma desmitificação da dita História oficial, favorecendo, por exemplo, estudos decoloniais. Tais estudos buscam romper com a escrita da História sob o ponto de vista do colonizador, por meio de outras maneiras de pensar, saber e sentir os fatos históricos, levando em consideração, para tanto, posicionamentos, projetos de resistência e criações de sujeitos que tendem a ser desconsiderados dentro da perspectiva da História vista de cima. Assim, esse tipo de fonte e de ator social, traz para o Ensino de História, uma perspectiva mais justa, emocionante e ampla, afinal de contas, como diria Eric Hobsbawm (1998), trata-se de "pessoas extraordinárias", pois o que realizam e pensam, faz a diferença.

Por fim, a trama aqui "narrada", urdida a partir da concepção de uma História problema, integrando as dimensões teóricas/normativas e as práticas educativas, focalizadas na relação entre as escolas, seus sujeitos e seu meio envolvente, é reveladora de como, através da História, a associação presente-passado e as trocas culturais por essa associação contemplada, devem ser entendidas. Não buscamos as origens, mas o ser humano, o seu tempo e tudo o que foi possível ser feito para a expansão da escola primária em Sergipe. Embora a tessitura aqui apresentada tenha sido 
pautada pela tentativa de equilíbrio e coerência, outras versões podem ser escritas, pois a História, longe de ser estática, continua...

\section{Referências}

ALBERTI, Verena. Ouvir contar: textos em história oral. Rio de Janeiro: Editora FGV, 2004.

BARRETO, Raylane Andreza Dias; MESQUITA, Ilka Miglio de; SANTOS, Laísa Dias. Por uma história da educação vista por sujeitos simples: cultura e práticas da escola primária no sul sergipano (1930-1960). Revista Educação: Porto Alegre. v. 38. n. 2, p. 249-262. 2015.

CHARTIER, Roger. A história cultural: entre práticas e representações. Tradução de Maria Manuela Galhardo. Rio de Janeiro: Bertrand Brasil, 1990.

CHARTIER, Roger. A história ou a leitura do tempo. Tradução de Cristina Antunes. 2. ed. Belo Horizonte: Autêntica Editora, 2010.

HALBWACHS, Maurice. A memória coletiva. São Paulo: Centauro, 2004.

HOBSBAWM, Eric J. Pessoas Extraordinárias: resistência, rebelião e jazz. São Paulo: Paz e Terra, 1998.

INSTITUTO NACIONAL DE ESTUDOS PEDAGÓGICOS (Brasil). Organização do ensino primário e normal: XVIII: Estado de Sergipe. Rio de Janeiro, 1950. 53 p. (Boletim, n. 54).

LE GOFF, Jacques. História e memória. Tradução Bernardo Leitão et al. Campinas/SP: Editora da Unicamp, 1990. (Coleção Repertórios).

SANTOS, Laísa Dias; SILVA, Rony Rei do Nascimento. Dos castigos e da disciplina: práticas escolares no território sul sergipano. Interfaces Científicas-Educação, Aracaju: Edunit, v. 1, p. 77-87, 2012.

SANTOS, Magno Francisco de Jesus. Ecos da modernidade: arquitetura dos grupos escolares sergipanos (1911-1926). São Cristóvão: Editora UFS, 2013.

SERGIPE. Decreto-lei n. 25, de 03 de fevereiro de 1931. Dá novo regulamento à Instrução primária do estado. Disponível em: Arquivo público do estado.

SERGIPE. Mensagem apresentada à Assembleia Legislativa do Estado, em 7 de setembro de 1936. Dr. Eronides Ferreira de Carvalho. Sergipe: Arquivo público do estado, 1936. 
SERGIPE. Mensagem apresentada à Assembleia Legislativa do Estado, no ano de 1948, pelo Governador do estado José Rollemberg Leite. Sergipe: Arquivo público do estado, 1948.

SERGIPE. Mensagem apresentada à Assembleia Legislativa do Estado, no ano de 1949, pelo Governador do estado José Rollemberg Leite. Sergipe: Arquivo público do estado, 1949.

SERGIPE. Mensagem apresentada à Assembleia Legislativa do Estado no ano de 1951, pelo Governador do Estado José Rollemberg Leite. Sergipe: Arquivo público do estado, 1951.

SERGIPE. Mensagem apresentada à Assembleia Legislativa do Estado, no ano de 1952, pelo Governador do estado Arnaldo Rollemberg Garcez.

Sergipe: Arquivo público do estado, 1952.

SERGIPE. Mensagem apresentada à Assembleia Legislativa do Estado, no ano de 1954, pelo Governador do estado Arnaldo Rollemberg Garcez.

Sergipe: Arquivo público do estado, 1954.

SERGIPE. Mensagem apresentada à Assembleia Legislativa do Estado, no ano de 1959, pelo Governador do estado Luiz Garcia. Sergipe: Arquivo público do estado, 1959.

SHARPE, Jim. A história vista de baixo. In: BURKE, Peter (org.). A escrita da história: novas perspectivas. Tradução de Magda Lopes. São Paulo: Editora Unesp, 2011. p. 39-64.

THOMPSON, Paul. A voz do passado: história oral. Rio de Janeiro: Paz e Terra, 1992. 